\title{
Description of a new species of Euderus Haliday from the southeastern United States (Hymenoptera, Chalcidoidea, Eulophidae): the crypt-keeper wasp
}

\author{
Scott P. Egan', Kelly L. Weinersmith', Sean Liu', Ryan D. Ridenbaugh², \\ Y. Miles Zhang ${ }^{2}$, Andrew A. Forbes ${ }^{3}$
}

I Department of BioSciences, Rice University, Houston, Texas, 770052 Department of Biology, University of Central Florida, Orlando, Florida, 328163 Department of Biology, University of Iowa, Iowa City, Iowa, 52242

Corresponding author: Scott P. Egan (scott.p.egan@rice.edu)

Academiceditor:J.Fernandez-Triana|Received8November2016|Accepted28December2016|Published 12January2017

http://zoobank.org/44345FF8-85C2-419B-95CD-87CF8BD37DC7

Citation: Egan SP, Weinersmith KL, Liu S, Ridenbaugh RD, Zhang MY, Forbes AA (2017) Description of a new species of Euderus Haliday from the southeastern United States (Hymenoptera, Chalcidoidea, Eulophidae): the cryptkeeper wasp. ZooKeys 645: 37-49. https://doi.org/10.3897/zookeys.645.11117

\begin{abstract}
A new species of the genus Euderus Haliday, Euderus set sp. n., is described and illustrated from the southeastern United States, where it parasitizes the crypt gall wasp, Bassettia pallida Ashmead, 1896, on live oaks in the genus Quercus (subsection Virentes). This is the $1^{\text {st }}$ species of the genus reported from the southeastern United States to parasitize cynipid gall wasps and the $3^{\text {rd }}$ species of the genus reported to attack cynipids in North America. Modified sections of the identification keys to subgenera and species of Euderus (Yoshimoto, 1971) are included to integrate the new species.
\end{abstract}

\section{Keywords}

Bassettia pallida, Chalcidoidea, Cynipidae, Euderus, Eulophidae, Quercus geminata, Quercus virginiana, new species 


\section{Introduction}

The genus Euderus Haliday, 1844 is a group of parasitic wasps in the family Eulophidae (Hymenoptera) with approximately 77 described species (Yoshimoto 1971, Noyes 2016). The genus has a cosmopolitan distribution, where it is found in North and South America, Europe, Asia, Australia, and many isolated island archipelagos, including the Hawaiian islands, Micronesia, the Canary Islands, and the Seychelles archipelago (Ahmad 1976, Askew et al. 2001, Báez and Askew 1999, Gates et al. 2002, Gibson et al. 2006, Goolsby et al. 2001, Gunasena and Harris 1998, Herting 1973, Thompson 1955, Yoshimoto 1971).

Yoshimoto (1971) produced the last revision of the genus Euderus for North America, north of Mexico. The revisions built off of Nearctic catalogues by Peck (1951, 1963) and Burks (1967), with new additions based on material deposited in the Canadian National Collection, material loaned from the Natural History Museum, London, Philadelphia Academy of Sciences, and the Museum of Comparative Zoology, Harvard University. Based on this revision, there are 22 species reported from North America north of Mexico, with 12 residing in the coastal southeastern U.S. (Florida, Alabama, Mississippi, Louisiana, and Texas; Yoshimoto 1971, Noyes 2016). According to Yoshimoto (1971), the biological records of Euderus from the U.S. indicate that most species are host specific on pupae of leaf tying, leaf mining, twig and fruit boring Lepidoptera (Tortricidae or Gelechiidae) and stem boring and other herbivorous Coleoptera (Buprestidae, Cerambycidae, and Curculionidae). Rarely, Euderus has been reported to attack gall-making Hymenoptera (Cynipidae) or exhibit hyperparasitism on other Hymenopteran parasitoids (Ichneumonidae). Detailed host records from field observation across the genus are summarized in Table 1 of Yoshimoto (1971).

Here, we report the first species of this genus from the southeastern United States to attack cynipid gall wasps, where it is associated with the crypt gall wasp Bassettia pallida Ashmead, 1896 (Hymenoptera; Cynipidae) on live oaks (Quercus; subsection Virentes), including Quercus virginiana and Q. geminata. We modify the key published by Yoshimoto (1971) to include the new species and add a correction to the key to subgenera.

\section{Materials and methods}

\section{Field collections and lab husbandry}

For the type locality, branches of the sand live oak, Quercus geminata, infested with the asexual generation of the crypt gall wasp, Bassettia pallida, were collected July 15, 2014, August 1, 2015, and October 1, 2015, in Inlet Beach, Florida (Lat/Long: 30.273663, -86.001911). Additional populations were collected across the U.S. Gulf coast on $Q$. geminata and Q. virginiana in 2014, 2015, and 2016 (see Table 1). Branches were placed in clear plastic cups, covered with a coffee filter and rubber band, and maintained outside in natural temperature and humidity conditions in a constantly shaded walkway at Rice University in Houston, Texas (Lat/Long: 29.717030, -95.401279). Emergence of all in- 
Table I. Confirmed localities for E. set associated with B. pallida galls on live oaks. (LA = lab emergence from a $B$. pallida gall; $\mathrm{D}=$ found during dissection of $B$. pallida gall).

\begin{tabular}{l|c|c|c|c}
\hline \multicolumn{1}{c|}{ Location } & Lat/Long & Host plant & Collection method & N \\
\hline Inlet Beach, FL & $30.273663,-86.001911$ & Q. geminata & LA, D & 158 \\
\hline Lake Lizzie, FL & $28.227718,-81.179641$ & Q. geminata & $\mathrm{D}$ & 12 \\
\hline Ochlocknee Bay, FL & $29.922913,-84.411060$ & Q. geminata & $\mathrm{D}$ & 7 \\
\hline Jekyll Island, GA & $31.073975,-81.424541$ & Q. virginiana & LA & 1 \\
\hline Gautier, MS & $30.382323,-88.611080$ & Q. virginiana & $\mathrm{D}$ & 3 \\
\hline Delcambre, LA & $29.968115,-91.981863$ & Q. virginiana & $\mathrm{D}$ & 2 \\
\hline Morgan City, LA & $29.693581,-91.159113$ & Q. virginiana & $\mathrm{D}$ & 1 \\
\hline Humble, TX & $29.998392,-95.184455$ & Q. virginiana & LA & 19 \\
\hline Rice Univ., TX & $29.716882,-95.401928$ & Q. virginiana & LA, D & 27 \\
\hline
\end{tabular}

dividuals was monitored regularly for a year or dissected out of $B$. pallida crypt galls in the lab. All individuals were preserved in $96 \% \mathrm{EtOH}$ and frozen in a $-80^{\circ} \mathrm{C}$ ultrafreezer.

\section{Morphological descriptions and type material locations}

Descriptions of the species have been made under a Leica M125 Stereoscope, with lighting achieved through a Leica LED5000 SLI - Spotlight illumination with 2 HiPower LEDs and a Leica TL5000 Transmitted Light Base with Rottermann Contrast TM, brightfield and two sided darkfield. For images, 75-150 stacked photographs were produced by a Canon 7D Mark II (Canon USA, Melville, NY), with a Mitutoyo M Plan Apo 10x objective mounted onto the Canon EF Telephoto $70-200 \mathrm{~mm}$ zoom lens, which was mounted on a Stackshot Automated Focus Stacking Macro Rail (Cognysis Inc., Traverse City, MI). The Canon MT-24EX Macro Twin Lite Flash with custom made diffusers was used to minimize hot spots. Images were processed using Zerene Stacker (Zerene Systems LLC., Richland, VA) and plates were finished with Adobe Illustrator CC. Pictures of slide-mounted wings were taken using a Leica ICC50W camera.

Morphological nomenclature follows Gibson et al. (1997), Yoder et al. (2010), and Hymenoptera Anatomy Consortium (2016). The identification key is modified from the key to subgenera and species of the genus Euderus in Yoshimoto (1971).

Type material is deposited in the American Museum of Natural History (AMNH) (Curator: Dr. James Carpenter; Collection Assistant: Christine LeBeau). AMNH specimen identification codes: Holotype - AMNH_IZC 00238642; 8 paratypes AMNH_IZC $00238643-00238650$.

\section{Complementing morphological taxonomy with molecular barcodes}

When samples were of sufficient quality for genetic work, we complemented morphological taxonomy with molecular barcodes (e.g., Smith et al. 2008, 2012, Forbes and 
Funk 2013, Forbes et al. 2016). Genomic DNA from two individuals from the Inlet Beach, FL population were extracted using DNeasy Blood and Tissue kits (Qiagen Inc., Valencia, CA). We used a pair of degenerate primers to amplify a segment of the mitochondrial cytochrome oxidase (mtCOI) gene using standard PCR protocols (Smith et al. 2008). Primers used were COI pF2: 5' - ACC WGT AAT RAT AGG DGG DTT TGG DAA - 3' and COI 2437d: 5' - GCT ART CAT CTA AAW AYT TTA ATW CCW G - 3', developed by Simon et al. (1994) and modified by Kaartinen et al. (2010). We treated amplified fragments with Exonuclease I (New England Biolabs, Ipswich, MA) and Shrimp Alkaline Phosphatase (Fermentas Life Sciences, Glen Burnie, MD) and sequenced in both forward and reverse directions on an ABI 3730 DNA analyzer using BigDye 3.1 sequencing chemistry (ThermoFisher Inc., Waltham, MA). We edited raw sequences and assembled forward and reverse reads using Geneious v.6.1.8 (Kearse et al. 2012). The final sequences were $703 \mathrm{bp}$ and $745 \mathrm{bp}$ in length, a function of amplification and sequencing success. We ran each sequence through the "identification request" module on the Barcode of Life Database (BOLD; Ratnasingham and Hebert 2007) to identify the highest percentage matches from previously identified taxa. All sequences were deposited in GenBank (accession numbers provided below).

\section{Results}

Details on the on the type material and type localityare provided, with a thorough description with images, a differential diagnosis of the new species, and a modification to the identification key published by Yoshimoto (1971) that distinguishes this new species from closely related species. We also provide a correction to the key to subgenera published in Yoshimoto (1971). In addition, we provide a brief description of etymology and information on the distribution, natural history, biology, and results of the mtDNA DNA barcoding analysis. In Supplemental File 1, we provide further details of the morphological, geographic, and ecological distinguishing features of this new Euderus species, Euderus set, which differentiate it from (1) ecologically similar Euderus species attacking cynpid gall wasps, (2) geographically overlapping Euderus species in the coastal southeastern United States, (3) geographically proximate Euderus speices from the Caribbean, and (4) morphologically similar species within the Euderus genus. We also provide the DNA sequence data to complement the morphological taxonomy in Suppl. material 1.

\section{Taxonomy}

Euderus Haliday, 1844

Euderus Haliday, 1844. Trans. Ent. Soc. Lond. 3: 298.

Type-species. Entedon amphis Walker. 


\section{Euderus set Egan, Weinersmith, \& Forbes, sp. n.} http://zoobank.org/44A7E50B-5E80-4A60-9170-DD1B9A7221B7

Figs 1-2 (3 panels per figure)

Material examined. Holotype,, , Inlet Beach, FL, collected July 15, 2015 by Scott P. Egan, AMNH ID\#: AMNH_IZC 00238642

Allotype, same data as holotype

Paratypes, $2 \hat{\jmath}$, same locality as holotype

Specimens from each collection locality (Table 1).

Description. FEMALE. Length $1.6-2.3 \mathrm{~mm}$. Holotype $2.3 \mathrm{~mm}$

Color. Head, scrobal depression, pedicel, flagellum, mesoscutum, scutellum, coxae and metasoma metallic, olive green to turquoise to iridescent blue (colors depends on lighting and age of specimen); antennal scape white to yellow; femora and tibiae concolorous with mesoscutum but color lightens apically; tarsi white, except terminal segment dark brown (Fig. 1A, B).

Head. Head in fresh specimens as wide as mesosoma; in dorsal view 2.9 times as broad as long; eyes prominent and bare; vertex, frons, and clypeus reticulate; vertex and upper frons distributed with white bristles; scrobal depression extends from slightly below anterior ocellus to level of lower eye margin, smooth above torulus and striolate below; toruli located in lower third of scrobal depression; clypeus short, subquadrate, only slightly longer than wide; malus sulcus inconspicuous and 0.44 times eye length; mandibles with three teeth. Antennal scape 3.5 times as long as broad and 0.6 times eye length; Flagellum with nine segments, with anellus two-segmented, funicle four-segmented, and clava three-segmented. Funicular segments each with 2 rows of thick, mostly non-overlapping bristles (Fig. 2B). Relative length of scape, pedicel, anelli, funicle 1, 2, 3, and 4, and clava 1,2, and 3 as $38,12,2,24,22,22,20,16,12,8$, respectively; two anelli with the same length but relative breadth of first anellus to second anellus as 6,8 .

Mesosoma. Pronotum, mesoscutum and scutellum reticulate; pronotum short in dorsal view, with six brown bristles at margin with mesoscutum; mesoscutum sparsely setose and setae inconspicuous; scutellum with many short setae and two pairs of strong setae in posterior third. Mesoscutum 0.95 as long as broad, mid-lobe convex, notauli complete and deep; axillae slightly advanced, their anterior tip extending to the approximate midpoint of the mesoscutum. Scutellum moderately convex and length 0.80 times length of mesoscutum. Propodeum 0.24 times length of scutellum and with strong median carina (Fig. 1B); callus with 6-7 bristles (Fig. 2A).

Wings. Forewing broad, extending past apex of gaster, marginal ciliae short; basal cell bare; submarginal vein with 6 dorsal bristles; postmarginal vein $1.3 \mathrm{x}$ length of stigmal vein; 3 admarginal hairs on left wing, four admarginal hairs on right wing; stigmal vein short and with large stigmus with 6 hairs on surface; 5 strongly-defined hair lines reaching dorsal and apical margin of forewing, with 3-4 additional less strongly defined hair lines that may or may not reach wing margin; 1 hair at median of radial cell (Fig. 2A). Hindwing 0.80 times length of forewing; hindwing moderately and evenly setose; hind marginal ciliae long. 

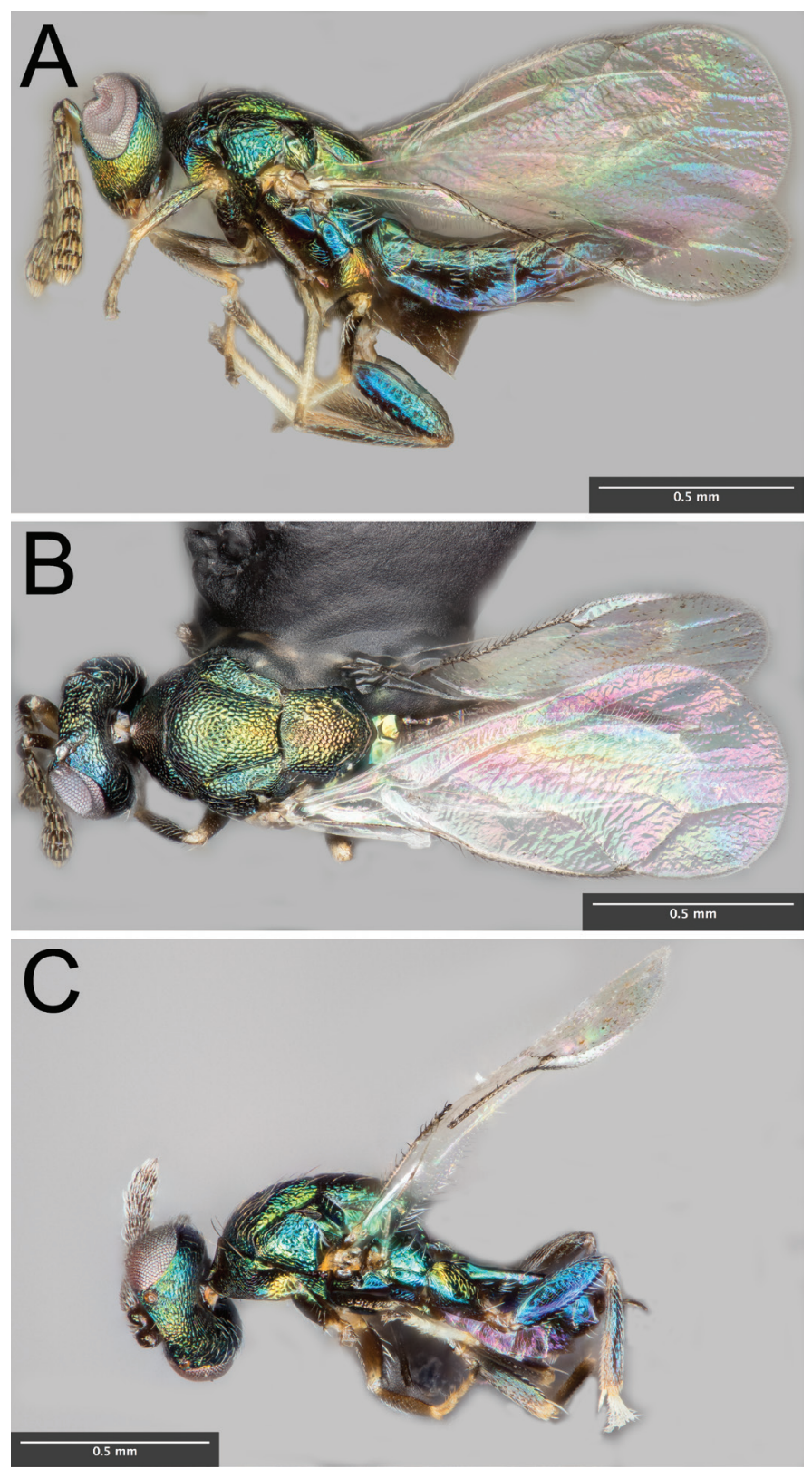

Figure I. A Lateral habitus of female Euderus set B Dorsal habitus of female Euderus set C Lateral habitus of male Euderus set.

Metasoma. Metasoma with petiole hidden in dorsal view; gaster elongate, 2.6 times as long as broad, and as long or longer than head and mesosoma combined; scattered white setae at posterior margins of each tergite becoming more dense towards 

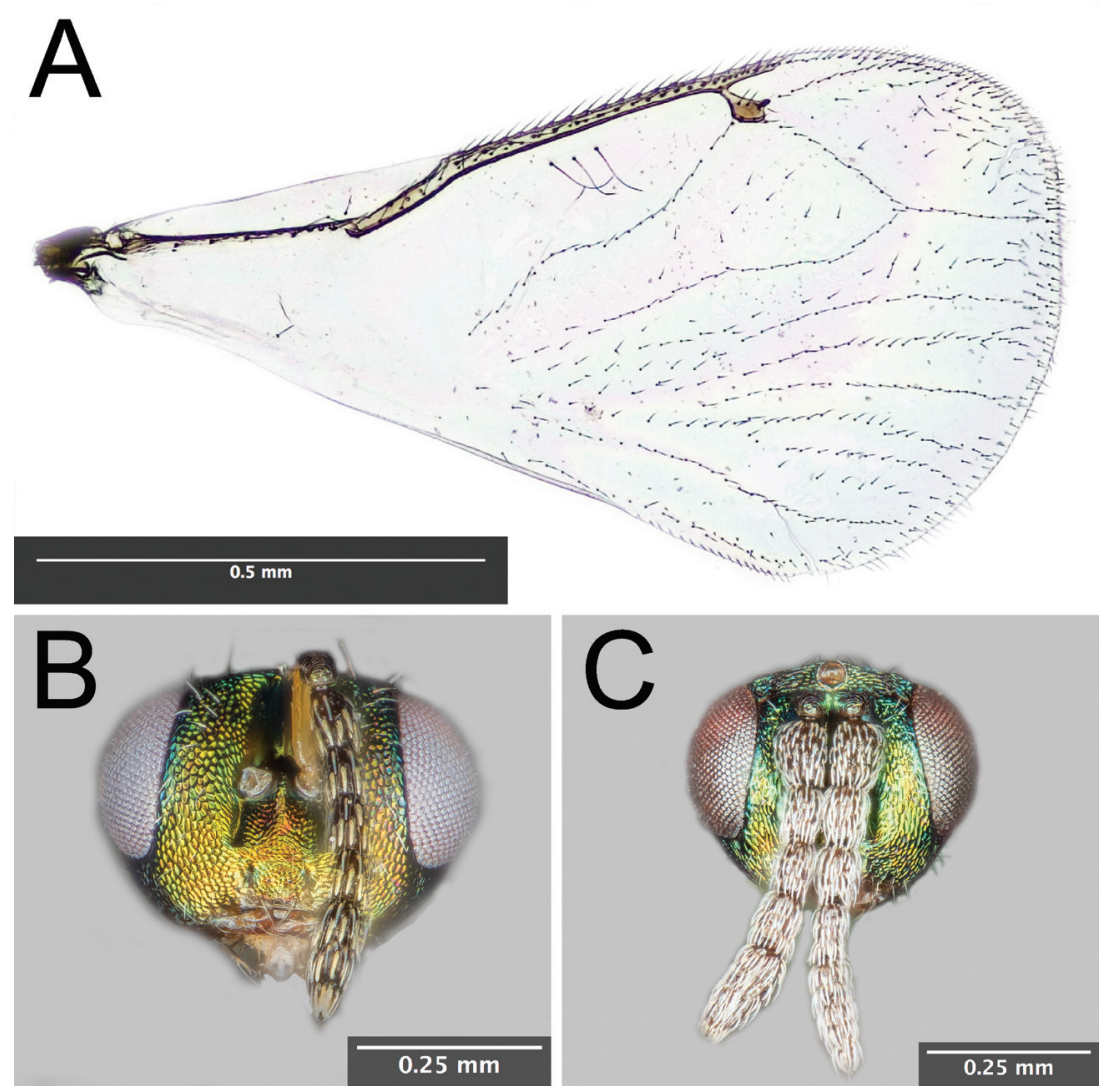

Figure 2. A Right forewing of male Euderus set B Anterior view of female Euderus set head C Anterior view of male Euderus set head.

the apex of the gaster; each cercus with two long bristles. Ovipositor extends slightly beyond apex of gaster (Fig. 1A).

MALE. Length $1.2-1.6 \mathrm{~mm}$. Antennae inserted in middle of face (Fig. 2C). Funicular segments each with 3 loosely ordered rows of fine bristles. Gaster ovate; shorter than head and thorax combined. Other characters similar to female.

Etymology. Named after the ancient Egyptian god Set, whose mythological stories mirror the natural biology of E. set. Set was the god of evil and chaos (Pinch 2004) and was reported to have control over evil animals like hyenas and serpents, just as $E$. set manipulates the behavior of its host, which is a parasite of trees (see Biology section below). The god Set is also reported to have trapped his brother Osiris in a crypt to kill him, later retrieving the body and chopping it up into small piece, which also fits with E. set, the crypt-keeper wasp, which kills its host in a crypt, and devours the host from the inside out, leaving major sections of exoskeleton (i.e., body parts) chopped up and distributed in the crypt (Weinersmith et al., in revision). 
Diagnosis. Two changes are required for the new species, E. set, to be included in the North American key to species of the genus Euderus by Yoshimoto (1971). First, a change is required to the key to subgenera of Euderus, where characters referring to the male flagellum should be removed. Yoshimoto (1971) used whorls of long hairs on the male flagellum as a diagnostic trait to discriminate between subgenera Neoeuderus and Euderus, but at that time only a single male specimen of subgenus Neoeuderus was available for study, and this individual was from the species $E$. viridilineatus for which no females had been found. As the male E. set. do not have antennae with pronounced whorls of long hairs, this is not an appropriate diagnostic trait for the subgenus.

We propose the following revision to the Yoshimoto (1971) key to subgenera:

4 Apical margin of fore wing with 5 hair lines; female antenna inserted at level of lower margin of eye; male antenna inserted about middle of face.... Neoeuderus

- $\quad$ Apical margin of fore wing with 3-4 hair lines (Fig. 2A); antenna of male and female inserted slightly above or at level of lower margin of eye (Fig. 2B, C) ....

Euderus

Secondly, Yoshimoto's (1971) key to the subgenus Neoenderus should be revised as follows:

3 Neck region of stigmal vein short, stigmus large (1.0) with 6-10 scattered hairs on surface, postmarginal vein between 1.2 and 1.5 times length of stigma vein; radial cell with one or more scattered hairs .................................... 4

- $\quad$ Neck of stigmal vein elongate, stigmus small (0.5), surface with 4 hairs; postmarginal vein 2 times length of stigma vein; radial cell bare.

multilineatus (Girault)

Surface of stigmus with 9-10 scattered hairs; submarginal vein with 7-8 dorsal bristles; 6 admarginal hairs; callus with 12 scattered hairs; apical region of radial cell with $>1$ scattered hairs crawfordi Peck

- $\quad$ Surface of stigmus with 4-6 scattered hairs; submarginal vein with 6 dorsal bristles; 3-4 admarginal hairs; radial cell with 1 hair at approximately its median; (Fig. 2A); callus with 6-7 scattered hairs (Fig. 1A, C); set

Molecular barcodes to complement morphological taxonomy. The two female Euderus set mtDNA-COI sequences were 98\% identical to each another and each was most similar to other previously identified Euderus in the BOLD database. Sequence 1 was $88.4 \%$ identical to Euderus sp. D0703 on BOLD and sequence 2 was $89.8 \%$ identical to another Euderus sp. on BOLD (Ratnasingham and Hebert 2007). See Supplemental File 1 for the two specific mtDNA sequences.

Distribution. Type locality for E. set is Inlet Beach, Florida, U.S. (Lat/Long: 30.273663, -86.001911), where it emerged from a stem crypt gall on Quercus geminata induced by the crypt gall wasp, Bassettia pallida. We have also collected B. pallida galls from live oaks across the Gulf coast of the southeastern United States, where additional $E$. set have been found, including additional sites in Georgia, Florida, Mississippi, Louisiana, and Texas (see Table 1). Generally, we expect $E$. set to be restricted to 
the range of live oaks (Quercus; subsection Virentes; Cavender-Bares et al. 2015) upon which Bassettia pallida induce galls (Melika and Abrahamson 2007).

Biology. The genus Euderus Haliday is a small group of chalcidoid wasps belonging to the family Eulophidae (Burks 2003) where the majority are reported to be primary parasitoids of arthropods at all stages of development (Burks 1979, Burks 2003, Noyes 2016). E. set parasitizes the crypt gall wasp Bassettia pallida Ashmead, 1896, which forms galls on American live oaks in the genus Quercus and the subsection Virentes across the southeastern United States (Ashmead 1896, Melika and Abrahamson 2007, Egan et al. 2013). There are six to eight different cynipid gall wasps that are highly specialized and form galls on this same live oak complex (Egan et al. 2013). We have reared out many of the parasitoids from this large community, including clearly documenting the community from another gall former, Belonocnema treatae (Forbes et al. 2016), but this is the first time we have observed a member of the genus Euderus in this system after two decades of work (Lund et al. 1996, Egan and Ott 2007, Egan et al. 2012, Egan et al. 2013, Egan, unpubl. data).

Published records almost certainly underestimate the diversity of subgenus Neoeuderus in North America, and many other species in the subgenus may also be specialist parasitoids of oak galling cynipids. Yoshimoto (1971) noted that the biological records of the Nearctic Euderus indicate that most species are host specific, while also cautioning that host records for Euderus are patchy and the result of field observation, which only represent the most common species where there are substantial rearing records. While Yoshimoto noted just four members of subgenus Neoeuderus, the current work adds a fifth, and we have recently reared another from the honey comb leaf gall wasp, Callirhytis favosa, on pin oak in Iowa. While this undescribed Euderus parasitoid of $C$. favosa has not yet been extensively studied, it is most similar in appearance to E. set, E. crawfordi, and E. multilineatus. If this truly is a different species, then three of the six species in subgenus Neoeuderus are known parasitoids of the oakassociated Cynipidae.

Emergence of E. set in the lab from field-collected B. pallida galls was concentrated from February to March coincident with new leaf growth of the host plants and adult maturation and emergence of the asexual generation Bassettia pallida (Melika and Abrahamoson 2007, Egan, unpubl. data). We also observed a smaller pulse in September and October, which could have been a natural occurrence, or induced by harvesting galled tissue and bringing it into a controlled environment. Regardless of harvest time (August or October), a similar emergence window was observed in February and March.

Euderus set is strongly associated with a behavioral phenotype in its host, the crypt gall wasp, Bassettia pallida, where infected gall wasps cut an emergence hole through the gall tissue as an adult, but then die and remain partially in the crypt to plug the emergence hole with its head (Weinersmith et al., in revision). When E. set emerges, it cuts an emergence hole directly through the head capsule plugging the hole (Weinersmith et al., in revision). The host's behavioral phenotype may benefit $E$. set by making it easier for the adult stage to emerge from the crypt (as it now only has to emerge through the parasitoid's head capsule, rather than through the tree stem itself; Weiner- 
smith et al., in review). This putative behavioral manipulation of the host by its parasitoid $E$. set is the first time this has been described by the species-rich and economically important Chalcidoidea and is also the inspiration behind both the scientific name, $E$. set, and the common name, the crypt-keeper wasp.

In addition to $E$. set, we have also reared eleven additional natural enemy species from Bassettia pallida galls on live oaks (Quercus; subsection Virentes), including two inquilines (genera Synergus and Ceroptres) and nine parasitoids including three species from the genus Sycophila, two species from genus Ormyrus, one each from the genera Eurytoma, Acaenacis, and Brasema, as well as a parasitoid from the platygastrid subfamily Platygastrinae that we have not yet been able to key to genus. The natural enemy community requires further description.

\section{Acknowledgements}

This research was funded, in part, by the Huxley Faculty Fellowship in Ecology and Evolutionary Biology at Rice University to KW. We would also like to thank Linyi Zhang, Rebecca Izen, and Gaston del Pino for assistance with lab rearing, Anna Ward for sequencing COI, Jennifer Greene for logistical support, and Mattheau Comerford and Alex Wild for building collaborations for photography.

\section{References}

Ahmad R (1976) Studies on Prays acmonias and its natural enemies in Pakistan. Entomophaga 21: 265-268. https://doi.org/10.1007/BF02371760

Ashmead WH (1896) Descriptions of new cynipidous galls and gall-wasps in the United States National Museum. Proceedings of the United States National Museum 19: 113-136. https://doi.org/10.5479/si.00963801.19-1102.113

Askew RR, Blasco-Zumeta J, Pujade-Villar J (2001) Chalcidoidea and Mymarommatoidea (Hymenoptera) of a Juniperus thurifera L. forest of Los Monegros region, Zaragosa. Monografias Sociedad Entomológica Aragonesa 4: 1-76.

Báez M, Askew RR (1999) New records of Chalcidoidea (Hymenoptera) from the Canary Islands. Boletin de la Asociation Española de Entomologia 23: 65-82.

Burks BD (1967) In: Krombein KV, Burks BD (Eds) Hymenoptera of America North of Mexico, synoptic catalog. Agriculture Monograph 2(Suppl. 2): 231-232. https://doi. org/10.5962/bhl.title.63670

Burks BD (1979) Torymidae (Agaoninae) and all other families of Chalcidoidea (excluding Encyrtidae). In: Krombein KV, Hurd PD Jr, Smith DR, Burks BD (Eds) Catalog of Hymenoptera in America North of Mexico, Smithsonian Institute Press, Washington, DC, 748-749, 768-889, 967-1043.

Burks RA (2003) Key to the Nearctic genera of Eulophidae, subfamilies Entedoninae, Euderinae, and Eulophinae (Hymenoptera; Chalcidoidea). World Wide Web electronic publication. http//cache.ucr.edu/\%7Eheraty/Eulophidae/ [accessed 15-07-2016] 
Cavender-Bares JA, Gonzalez-Rodriguez DA, Eaton AA, Hipp L, Beulke, Manos PS (2015) Phylogeny and biogeography of the American live oaks Quercus subsection Virentes): a genomic and population genetics approach. Molecular Ecology 24: 3668-3687. https:// doi.org/10.1111/mec.13269

Egan SP, Ott JR (2007) Host plant quality and local adaptation determine the distribution of a gall-forming herbivore. Ecology 88: 2869-2879. https://doi.org/10.1890/06-1303.1

Egan SP, Hood GR, Feder JL, Ott JR (2012) Divergent host plant use promotes reproductive isolation among cynipid gall wasp populations. Biology Letters 8: 605-608. https://doi. org/10.1098/rsbl.2011.1205

Egan SP, Hood GR, DeVela G, Ott JR (2013) Parallel patterns of morphological and behavioral variation among host-associated populations of two gall wasp species. PLoS ONE 8: e54690. https://doi.org/10.1371/journal.pone.0054690

Forbes AA, Funk DJ (2013) Aspects of the natural history of Neochlamisus (Coleoptera: Chrysomelidae) II: Characterization of parasitoid guilds from different plant hosts. Annals of the Entomological Society of America 106: 818-831. https://doi.org/10.1603/AN12151

Forbes AA, Hood GR, Hall MC, Lund J, Izen R, Egan SP, Ott JR (2016) Parasitoids, hyperparasitoids and inquilines associated with the sexual and agamic generations of the oak gall former, Belonocnema treatae (Hymenoptera: Cynipidae). Annals of the Entomological Society of America 109: 49-63. https://doi.org/10.1093/aesa/sav112

Gates MW, Heraty JM, Schauff ME, Wagner DL, Whitfield JB, Wahl DB (2002) Survey of the parasitic Hymenoptera on leafminers in California. Journal of Hymenoptera Research 11: 213-270.

Gibson GAP, Huber JT, Woolley JB (Eds) (1997) Annotated keys to the genera of Nearctic Chalcidoidea (Hymenoptera). National Research Council of Canada Research Press, Ottawa, 794 pp.

Gibson GAP, Gillespie DR, Dosdall L (2006) The species of Chalcidoidea (Hymenoptera) introduced to North America for biological control of the cabbage seedpod weevil, and the first recovery of Stenomalina gracilis (Chalcidoidea: Pteromalidae). Canadian Entomologist 138: 288-289.

Goolsby JA, Burwell CJ, Makinson J, Driver F (2001) Investigation of the biology of the hymenoptera associated with Fergusonina sp. (Diptera: Fergusoninidae) a gall fly of Melaleuca quinquenervia integrating molecular techniques. Journal of Hymenoptera Research 10: $163-180$.

Gunasena GH, Harris MK (1988) Parasites of hickory shuckworm and pecan nut casebearer with five new host-parasite records. Southwestern Entomologist 13: 107-111.

Haliday AH (1844) Contributions towards the classification of the Chalcididae. Transactions of the Entomological Society of London 3: 295-301.

Herting B (1973) Coleoptera to Strepsiptera. A catalogue of parasites and predators of terrestrial arthropods. Section A. Host or Prey/Enemy 3: 121.

Hymenoptera Anatomy Consortium (2016) Hymenoptera Anatomy Consortium. http://glossary.hymao.org [accessed on 24 Dec 2016]

Kaartinen R, Stone GN, Hearn J, Lohse K, Roslin T (2010) Revealing secret liaisons: DNA barcoding changes our understanding of food webs. Ecological Entomology 35: 623-623. https://doi.org/10.1111/j.1365-2311.2010.01224.x 
Kearse M, Moir R, Wilson A, Stones-Havas S, Cheung M, Sturrock S, Buxton S, Cooper A, Markowitz S, Duran C, Thierer T, Ashton B, Meintjes P, Drummond A (2012) Geneious basic: An integrated and extendable desktop software platform for the organization and analysis of sequence data. Bioinformatics 28: 1647-1649. https://doi.org/10.1093/bioinformatics/bts199

Lund JN, Ott JR, Lyons R (1998) Heterogony in Belonocnema treatae Mayr (Hymenoptera: Cynipidae). Proceedings of the Entomological Society of Washington 100: 755-763.

Melika G, Abrahamson WG (2007) Review of the nearctic gallwasp species of the genus Bassettia Ashmead, 1887, with description of new species (Hymenoptera: Cynipidae: Cynipini). Acta Zoologica Academiae Scientiarum Hungaricae 53: 131-148.

Noyes JS (2016) Universal Chalcidoidea Database. http://www.nhm.ac.uk/chalcidoids Peck O (1951) Superfamily Chalcidoidea. In: Muesebeck CFW, Krombein KV, Townes HK (Eds) Hymenoptera of America north of Mexico - synoptic catalog. Agriculture Monographs. U.S. Department of Agriculture 2: 462.

Peck O (1963) A catalogue of Nearctic Chalcidoidea (Insecta: Hymenoptera). The Memoirs of the Entomological Society of Canada 95: 5-1092. https://doi.org/10.4039/entm9530fv

Pinch G (2004) Egyptian Mythology: A Guide to the Gods, Goddesses, and Traditions of Ancient Egypt. Oxford University Press, Oxford, 272 pp.

Ratnasingham S, Hebert PDN (2007) BOLD: The barcode of life data system. Molecular Ecology Notes 7: 355-364. https://doi.org/10.1111/j.1471-8286.2007.01678.x

Simon C, Frati F, Beckenbach A, Crespi B, Liu H, Flook P (1994) Evolution, weighting, and phylogenetic utility of mitochondrial gene sequences and a compilation of conserved polymerase chain reaction primers. Annals of the Entomological Society of America 87: 651-701. https://doi.org/10.1093/aesa/87.6.651

Smith MA, Rodriguez JJ, Whitfield JB, Deans AR, Janzen DH, Hallwachs W, Hebert PDN (2008) Extreme diversity of tropical parasitoid wasps exposed by iterative integration of natural history, DNA barcoding, morphology, and collections. Proceedings of the National Academy of Science USA 105: 12359-12364. https://doi.org/10.1073/pnas.0805319105

Smith MA, Fernández-Triana JL, Eveleigh E, Gómez J, Guclu C, Hallwachs W, Hebert PDN, Hrcek J, Huber JT, Janzen D, Mason PG, Miller S, Quicke DL, Rodriguez JJ, Rougerie R, Shaw MR, Várkonyi G, Ward DF, Whitfield JB, Zaldívar-Riverón A (2012) DNA barcoding and the taxonomy of Microgastrinae wasps (Hymenoptera, Braconidae): Impacts after 8 years and nearly 20,000 sequences. Molecular Ecology Resources 13: 168-176. https:/doi. org/10.1111/1755-0998.12038

Thompson WR (1955) A catalogue of the parasites and predators of insect pests (Section 2) Host parasite catalogue, Part 3. Hosts of the Hymenoptera (Calliceratid to Evaniid). Commonwealth Agricultural Bureaux, The Commonwealth Institute of Biological Control, Ottawa, Ontario, 284 pp.

Weinersmith KL, Liu S, Forbes AA, Egan SP (in review) Tales from the crypt: A parasitoid manipulates emergence behavior in a crypt-forming gall wasp.

Yoder MJ, Mikó I, Seltmann KC, Bertone MA, Deans AR (2010) A gross anatomy ontology for Hymenoptera. PLoS ONE 5(12): e15991. https://doi.org/10.1371/journal.pone.0015991

Yoshimoto CM (1971) Revision of the genus Euderus of America north of Mexico. Canadian Entomologist 103: 541-578. https://doi.org/10.4039/Ent103541-4 


\section{Supplementary material I}

Morphological, geographic, and ecological distinguishing features of Euderus set Authors: Scott P. Egan, Kelly L. Weinersmith, Sean Liu, Ryan D. Ridenbaugh, Y. Miles Zhang, Andrew A. Forbes

Data type: PDF File

Copyright notice: This dataset is made available under the Open Database License (http://opendatacommons.org/licenses/odbl/1.0/). The Open Database License $(\mathrm{ODbL})$ is a license agreement intended to allow users to freely share, modify, and use this Dataset while maintaining this same freedom for others, provided that the original source and author(s) are credited. 